\title{
Incidental Carcinoma after Cholecystectomy for Benign Disease of the Gallbladder: A Meta-Analysis
}

\author{
Jung-Soo Pyo ${ }^{1} \mathbb{D}$, Byoung Kwan Son ${ }^{2, *} \mathbb{1}$, Hyo Young Lee ${ }^{2}$, Il Whan $\mathrm{Oh}^{2}$ and \\ Kwang Hyun Chung ${ }^{2}(\mathbb{D}$ \\ 1 Department of Pathology, Daejeon Eulji University Hospital, Eulji University School of Medicine, \\ Daejeon 35233, Korea; jspyo@eulji.ac.kr \\ 2 Department of Internal Medicine, Nowon Eulji University Hospital, Eulji University School of Medicine, \\ Seoul 01830, Korea; 2hyo0@eulji.ac.kr (H.Y.L.); 20180121@eulji.ac.kr (I.W.O.); kh.chung@eulji.ac.kr (K.H.C.) \\ * Correspondence: sbk1026@eulji.ac.kr; Tel.: +82-2-970-8204; Fax: +82-2-970-8621
}

Received: 23 April 2020; Accepted: 11 May 2020; Published: 14 May 2020

\begin{abstract}
This study aimed to determine the incidence and the prognosis of incidental carcinoma of the gallbladder (IGBC) after cholecystectomy through a meta-analysis. This meta-analysis included 51 studies and 436,636 patients with cholecystectomy. The incidence rate of IGBC after cholecystectomy was $0.6 \%$ (95\% confidence interval (CI) $0.5-0.8 \%$ ). The incidence rate of recent studies was not significantly different from those of past studies. The mean age and female ratio of the IGBC subgroup were not significantly different from those of the overall patient group. The estimated rates of IGBC were $13.0 \%, 34.1 \%, 39.7 \%, 22.7 \%$, and $12.5 \%$ in the pTis, pT1, pT2, pT3, and pT4 stages, respectively. Patients with IGBC had a favorable overall survival rate compared to patients with non-IGBC (hazard ratio (HR) $0.574,95 \%$ CI 0.445-0.739). However, there was no significant difference of disease-free survival between the IGBC and non-IGBC subgroups (HR 0.931, 95\% CI 0.618-1.402). IGBC was found in $0.6 \%$ of patients with cholecystectomy. The prognosis of patients with IGBC was favorable compared to those with non-IGBC. In the pathologic examination after cholecystectomy for benign diseases, a sufficient examination for histology should be guaranteed to detect IGBC.
\end{abstract}

Keywords: gallbladder; incidental carcinoma; incidence; prognosis; meta-analysis

\section{Introduction}

Gallbladder cancer (GBC), which is the most common biliary tract carcinoma, has nonspecific signs and symptoms and is sometimes indistinguishable from benign disease of the gallbladder (GB) [1]. Representative radiologic findings of GBC include wall thickening or mass-forming. The most common finding of radiology is wall thickening [2]. However, because the GB wall may be thickened by coexisting benign disease, such as cholelithiasis, the masking of GBC can occur. In addition, these radiologic findings of GBC are not specific and may be overlapped with benign diseases of the GB, such as focal adenomyomatosis or GB polyps [2]. Therefore, GBCs cannot be detected in preoperative radiologic examinations. GBCs, which are identified in the pathologic examination after cholecystectomy, are defined as incidental GBC (IGBC).

The incidence rate of IGBC after cholecystectomy was found to range up to $2.9 \%$ and this varied according to reports [3-53]. However, IGBC may be up to 50\% of all GBCs [54]. GBC is the fifth most common malignant tumor of the gastrointestinal tract, with an incidence of $0.8-1.2 \%$ [55]. In healthy populations, the prevalence of cholecystectomy, which is one of the most common surgeries performed, were $1.3 \%, 2.9 \%$, and $11.1 \%$ in Taiwan, Brazil, and German, respectively [10,56]. The different prevalences of cholecystectomy can affect the detection rate of IGBC. Cholelithiasis, which is an important cause for cholecystectomy, are affecting 10\% to $15 \%$ of the adult population of developed 
countries [57]. In the diagnosis of GBC, pathologic examinations after cholecystectomy are essential for the detection of IGBC. Cholelithiasis is the most common risk factor of GBC [5]. The risk factors of IGBC include old age, female, cholelithiasis, and obesity [1]. Preoperatively, the suspicious clinical and radiologic findings of IGBC are not specific, and the risk factors of IGBC and non-IGBC are overlapped [2]. The performance rates of pathologic examinations after cholecystectomy may be varied according to the country and insurance policy [25]. If the pathologic examinations after cholecystectomy were not performed in every case, the incidence rate of IGBC might be overestimated or underestimated. When this information for IGBC is accurate, further studies for the treatment of IGBC and predictions of the prognosis will be possible. In the present study, we aimed to elucidate the incidence rate of IGBC and the prognosis of IGBC through a meta-analysis. In addition, to obtain the clinicopathologic characteristics of IGBC, the mean age and compositions of the female ratio and $\mathrm{pT}$ stage were analyzed and compared to those of GBC overall.

\section{Materials and Methods}

\subsection{Published Study Search and Selection Criteria}

The literature search was performed using the PubMed databases through 31 July 2019. The search was performed using the following keywords: "cholecystectomy", "unsuspected or incidental", and "cancer or carcinoma or malignant or malignancy." The titles and abstracts of the searched articles were primarily screened for exclusion. Literature or systematic review articles were also screened to find additional eligible studies. The inclusion and exclusion criteria were as follows: (1) studies for the cholecystectomy by IGBCs in human samples were included and (2) non-original articles, such as case reports or review articles, were excluded.

\subsection{Data Extraction}

For the meta-analysis, data were extracted from the eligible studies [3-53] as follows: the first author's name, study location, study year, type of study and initial surgery, number of patients analyzed, patients' age and sex, tumor stage of IGBC, and survival rate. For the quantitative aggregation of the survival results, the correlation between IGBC and survival rate was analyzed according to the hazard ratio (HR), using one of three methods. In studies not reporting the HR or its confidence interval (CI), these variables were calculated from the presented data using the HR point estimate, log-rank statistic or its $p$-value, and the O-E statistic (the difference between the number of observed and expected events) or its variance.

If those data were unavailable, the HR was estimated using the total number of events, the number of patients at risk in each group, and the log-rank statistic or its $p$-value. Finally, if the only useful data were in the form of graphical representations of survival distributions, the survival rates were extracted at specified times to reconstruct the HR estimate and its variance under the assumption that the patients were censored at a constant rate during the time intervals. The published survival curves were evaluated independently by two authors to reduce variability. The HRs were then combined into an overall HR using Peto's method [58].

\subsection{Statistical Analyses}

In the present meta-analysis, all data were analyzed and obtained through the Comprehensive Meta-Analysis software package (Biostat, Englewood, NJ, USA). The incidence rates of IGBC after cholecystectomy were investigated from individual studies and analyzed through a meta-analysis. We performed the subgroup analysis based on the type of initial surgery and study, and the study year. The patient's age and sex were compared between IGBC and overall GBC patients. In this meta-analysis, among fixed and random effect models, for interpretation we used the values of a random-effects model. The heterogeneity between eligible studies was assessed using $Q$ and $\mathrm{I}^{2}$ statistics and presented using $p$-values. In addition, the sensitivity analysis was conducted to assess the heterogeneity of eligible 
studies and the impact of each study on the combined effect. Subgroup analyses were performed based on the type of initial surgery and study, the patients' age and sex, and the pT stage. The statistical significances between subgroups were evaluated through a meta-regression test. To consider the publication bias, Egger's test was used. If a significant publication bias was found, the fail-safe $\mathrm{N}$ and trim-fill tests were performed to confirm the degree of publication bias. A $p$-value $<0.05$ was considered significant.

\section{Results}

\subsection{Selection and Characteristics of Studies}

A total of 478 studies were identified in the database searching for the meta-analysis. Finally, 51 studies were selected according to the inclusion and exclusion criteria. Among the searched studies, 184 studies were excluded due to a lack of sufficient information. In addition, 160 reports were excluded due to being non-original articles. Other remaining reports were excluded for the following reasons: focusing on other diseases $(n=52)$, articles in a language other than English $(n=29)$, and duplicate articles $(n=2)$ (Figure 1). The characteristics of the eligible studies are shown in Table 1.

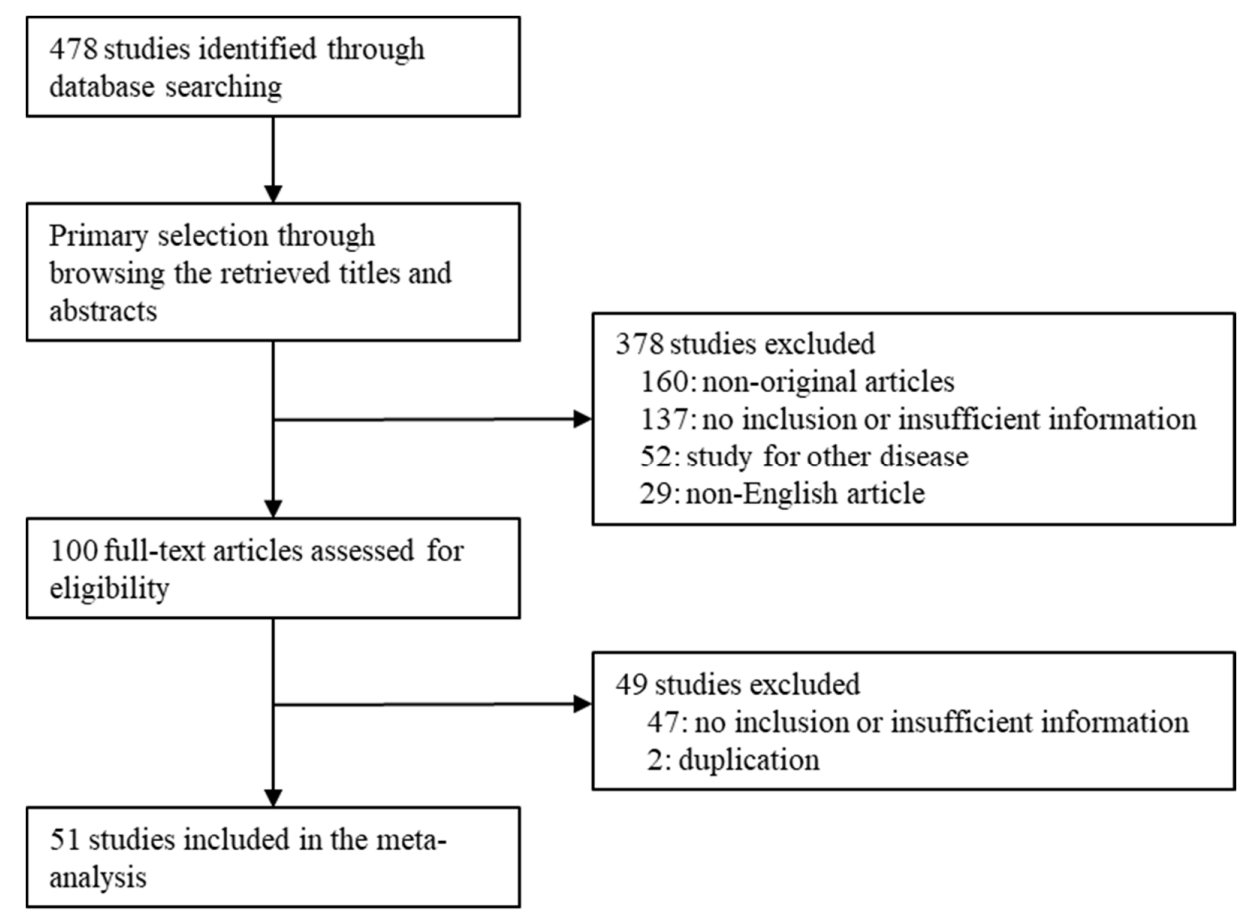

Figure 1. Flow chart of the study search and selection methods.

Table 1. Main characteristics of the eligible studies.

\begin{tabular}{|c|c|c|c|c|c|c|c|c|c|c|c|c|}
\hline \multirow{2}{*}{ First Author, Year } & \multirow{2}{*}{ Location } & \multirow{2}{*}{$\begin{array}{l}\text { Study } \\
\text { Year }\end{array}$} & \multirow{2}{*}{$\begin{array}{c}\text { Using } \\
\text { Registry }\end{array}$} & \multirow{2}{*}{$\begin{array}{c}\text { Initial } \\
\text { Surgery }\end{array}$} & \multicolumn{2}{|c|}{ No of Patients } & \multicolumn{6}{|c|}{ Tumor Stage } \\
\hline & & & & & Total & IGBC & $T x$ & Tis & T1 & T2 & T3 & T4 \\
\hline Ahn 2016 & Korea & 1998-2014 & & ND & 4629 & 73 & & & & & & \\
\hline Aoki 2002 & Japan & 1990-1999 & & $\mathrm{LC}$ & 990 & 11 & & 5 & & 6 & & \\
\hline Apodaca-Rueda 2017 & Brazil & 2010-2015 & & ND & 893 & 13 & & & & & & \\
\hline Basak 2016 & Turkey & $2009-2013$ & & LC/Open & 1747 & 4 & & & & 3 & 1 & \\
\hline Braghetto 1999 & Chile & 1992-1998 & & LC & 6500 & 15 & & & 4 & 5 & 6 & \\
\hline Cavallaro 2012 & Italy & 1998-2008 & & LC & 1480 & 9 & & 1 & 4 & 4 & & \\
\hline Chan 2003 & Taiwan & 1992-2000 & & $\mathrm{LC}$ & 1825 & 11 & & & 3 & 4 & 3 & 1 \\
\hline Charfi 2018 & Tunisia & $2003-2016$ & & LC/Open & 20,584 & 155 & & & 18 & 68 & 36 & 33 \\
\hline Choi 2009 & Korea & $2002-2007$ & & LC & 3145 & 33 & & & 12 & 17 & 4 & \\
\hline Cziupka 2012 & Germany & 2001-2009 & & ND & ND & 12 & & & 3 & 5 & 3 & 1 \\
\hline D'Hondt 2013 & Belgium & 1998-2008 & & LC/Open & ND & 45 & & & & & & \\
\hline Dorobisz 2016 & Poland & 1990-2014 & & LC/Open & 7314 & 64 & & & & & & \\
\hline
\end{tabular}


Table 1. Cont.

\begin{tabular}{|c|c|c|c|c|c|c|c|c|c|c|c|c|}
\hline \multirow{2}{*}{ First Author, Year } & \multirow{2}{*}{ Location } & \multirow{2}{*}{$\begin{array}{l}\text { Study } \\
\text { Year }\end{array}$} & \multirow{2}{*}{$\begin{array}{l}\text { Using } \\
\text { Registry }\end{array}$} & \multirow{2}{*}{$\begin{array}{l}\text { Initial } \\
\text { Surgery }\end{array}$} & \multicolumn{2}{|c|}{ No of Patients } & \multicolumn{6}{|c|}{ Tumor Stage } \\
\hline & & & & & Total & IGBC & $T x$ & Tis & T1 & $\mathrm{T} 2$ & T3 & $\mathrm{T} 4$ \\
\hline Duzkoylu 2015 & Turkey & 2005-2013 & & LC & 8698 & 15 & & 3 & 2 & 5 & 3 & \\
\hline Ferrarese 2013 & Italy & 2008-2012 & & $\mathrm{LC}$ & 508 & 7 & & & & 5 & 2 & \\
\hline Firat 2019 & Turkey & 2015-2017 & & LC/Open & 1112 & 7 & & 1 & 3 & 3 & & \\
\hline Genc 2011 & Turkey & 1999-2010 & & LC & 5164 & 5 & & 1 & 1 & 1 & 2 & \\
\hline Geramizadeh 2018 & Iran & $2010-2016$ & & LC/Open & 4872 & 18 & & & 10 & 8 & & \\
\hline Glauser 2011 & Switzerland & ND & Yes & LC/Open & 30,960 & 69 & & 2 & 14 & 34 & 14 & 5 \\
\hline Goussous 2018 & USA & $2000-2013$ & & LC/Open & 5796 & 26 & & & & & & \\
\hline Gulwani 2015 & India & 2001-2013 & & LC & 2926 & 23 & & & 5 & 14 & 4 & \\
\hline Horkoff 2019 & Canada & 2001-2015 & Yes & LC/Open & 11,4951 & 129 & & & & & & \\
\hline Ioannidis 2013 & Greece & $1992-2001$ & & LC/Open & 1536 & 14 & & & 5 & 6 & 3 & \\
\hline Jha2018 & India & 2014-2016 & & LC/Open & 4800 & 20 & & & 18 & 2 & & \\
\hline Kalita 2013 & India & $2009-2012$ & & LC/Open & 4107 & 18 & & 1 & 7 & 10 & & \\
\hline Kim 2010 & Korea & 1997-2008 & & LC/Open & 2607 & 26 & & 1 & 6 & 17 & 2 & \\
\hline Koppatz 2018 & Finland & $2010-2012$ & & LC/Open & 2034 & 10 & & & & & & \\
\hline Kwon 1997 & Korea & 1990-1996 & & ND & 527 & 10 & & & 5 & 3 & 2 & \\
\hline Kwon 2008 & Japan & 1992-2004 & & $\mathrm{LC}$ & 1793 & 38 & & & 20 & 17 & 1 & \\
\hline Lundgren 2018 & Sweden & $2007-2014$ & Yes & LC/Open & 36,010 & 213 & 23 & 14 & 41 & 72 & 51 & 12 \\
\hline Martins-Filho 2015 & Brazil & $2007-2010$ & & LC/Open & 2018 & 10 & & & & & & \\
\hline Mazer 2012 & USA & $1984-2008$ & & ND & ND & 443 & & & & & & \\
\hline Mitrovic 2010 & Bosnia et al. & ND & & LC/Open & 3007 & 21 & & & & & & \\
\hline Mori 1997 & Japan & 1991-1995 & & LC & 456 & 13 & & & 9 & 3 & 1 & \\
\hline Nitta 2018 & Japan & 2009-2017 & & LC/Open & 529 & 8 & & 2 & 1 & 3 & 2 & \\
\hline Panebianco 2013 & Italy & 2003-2011 & & LC & 1188 & 6 & & & 1 & 2 & 3 & \\
\hline Patel 2016 & UK & $2008-2013$ & & LC/Open & 4027 & 7 & & 1 & 2 & 2 & 2 & \\
\hline Pitt 2014 & USA & 2005-2009 & Yes & LC/Open & 91,260 & 170 & & & & & & \\
\hline Sarli 2000 & Italy & 1992-1999 & & LC/Open & 2300 & 20 & & 1 & 6 & 4 & 9 & \\
\hline Shimizu 2006 & Japan & 1991-2004 & & LC & 1195 & 10 & & & 4 & 5 & 1 & \\
\hline Solaini 2014 & UK & 2005-2012 & & LC/Open & 864 & 7 & & & & & & \\
\hline Talreja 2016 & Pakistan & 2005-2015 & & LC & 964 & 11 & & 1 & 4 & 6 & & \\
\hline Tantia 2009 & India & 2004-2007 & & $\mathrm{LC}$ & 3205 & 19 & & 8 & 8 & 3 & & \\
\hline Tatli 2017 & Italy & 2013-2016 & & LC/Open & 341 & 7 & & & 3 & 4 & & \\
\hline Tian 2015 & China & $2002-2012$ & & LC & 7582 & 69 & & & 22 & 16 & 13 & 18 \\
\hline Utsumi 2017 & Japan & $2008-2015$ & & LC & 352 & 8 & & & 3 & 4 & 1 & \\
\hline Vega 2019 & USA & 1999-2016 & & ND & ND & 11 & & & & & & \\
\hline Xu 2013 & China & $1993-2011$ & & $\mathrm{LC}$ & 8005 & 36 & & & 16 & 11 & 9 & \\
\hline Yamamoto 2005 & Japan & 1991-2003 & & LC & 1663 & 9 & & 1 & 3 & 5 & & \\
\hline Yi 2013 & China & 1992-2009 & & LC/Open & 14073 & 38 & & & 14 & 4 & 13 & 7 \\
\hline Zhang 2015 & China & 1999-2007 & & LC & 11574 & 28 & & 4 & 9 & 8 & 5 & 2 \\
\hline Zhu 2015 & China & $2000-2010$ & & LC & 4014 & 29 & & & 11 & 14 & 4 & \\
\hline
\end{tabular}

No, number; IGBC, incidental gallbladder cancer; Tis, in situ; ND, no description; LC, laparoscopic cholecystectomy.

\subsection{The Incidence Rate of IGBC after Cholecystectomy}

The incidence rate of IGBC after cholecystectomy was $0.6 \%$ (95\% confidence interval (CI) $0.5-0.8 \%$ ) in overall patients (Table 2). The incidence rate of IGBC after laparoscopic cholecystectomy was $0.7 \%$ (95\% CI $0.5-0.9 \%)$. The incidence rate of the subgroup using the patients' registry was significantly lower than that of subgroup using individual hospital data $(0.2 \%$ vs. $0.7 \% ; p=0.002$ in the meta-regression test). However, there were no significant differences of incidence rates between study years.

Table 2. The estimated rates of incidental gallbladder cancer after cholecystectomy.

\begin{tabular}{cccccc}
\hline Subgroup & $\begin{array}{c}\text { Number of } \\
\text { Subsets }\end{array}$ & $\begin{array}{c}\text { Fixed Effect } \\
{[\mathbf{9 5 \%} \text { CI] }}\end{array}$ & $\begin{array}{c}\text { Heterogeneity } \\
\text { Test }(\boldsymbol{p} \text {-Value })\end{array}$ & $\begin{array}{c}\text { Random Effect } \\
{[\mathbf{9 5 \%} \text { CI] }}\end{array}$ & $\begin{array}{c}\text { Egger's Test } \\
(\boldsymbol{p} \text {-Value })\end{array}$ \\
\hline Overall & 47 & $0.005[0.005,0.005]$ & $<0.001$ & $0.006[0.005,0.008]$ & 0.070 \\
Laparoscopic & 21 & $0.007[0.007,0.008]$ & $<0.001$ & $0.007[0.005,0.009]$ & 0.517 \\
\hline Using registry & 4 & $0.003[0.002,0.003]$ & $<0.001$ & $0.002[0.001,0.005]$ & 0.499 \\
Individual & 43 & $0.007[0.007,0.008]$ & $<0.001$ & $0.007[0.006,0.008]$ & 0.294 \\
\hline Included 1990's & 19 & $0.007[0.006,0.007]$ & $<0.001$ & $0.007[0.004,0.010]$ & 0.972 \\
Included 2000's & 21 & $0.004[0.004,0.004]$ & $<0.001$ & $0.006[0.004,0.008]$ & 0.253 \\
after 2010 year & 6 & $0.006[0.005,0.008]$ & $<0.001$ & $0.007[0.004,0.012]$ & 0.198 \\
\hline
\end{tabular}


Next, the patients' age and sex of IGBC were investigated and compared with overall GBC. Patients with IGBC had a significantly older age than the overall patients $(p<0.001$ in meta-regression test). The patients' age of IGBC and overall GBC were 65.291 (95\% CI 63.867-66.715) and 52.023 (95\% CI 49.208-54.839), respectively (Table 3). The female ratio of IGBC was $69.4 \%$ (95\% CI $66.0-72.7 \%$ ). There was no significant difference of female ratio between IBC and overall GBC ( $p=0.817$ in the meta-regression test). The age and female ratio was higher in the subgroup using the registry than in the subgroup using the individual hospital data. The IGBC showed the highest rate in the pT2 stage than in other pT stages (Table 4). The estimated rates of IGBC were 13.0\% (95\% CI 7.9-20.6\%), $34.1 \%$ (95\% CI $28.3-40.3 \%), 39.7 \%$ (95\% CI $34.8-44.8 \%), 22.7 \%$ (95\% CI $19.5-26.4 \%)$, and $12.5 \%$ (95\% CI $7.3-20.6 \%$ ) in the pTis, pT1, pT2, pT3, and pT4 stages, respectively.

Table 3. Comparisons of age and female ratio between incidental and non-incidental gallbladder cancers.

\begin{tabular}{cccccc}
\hline Subgroup & $\begin{array}{c}\text { Number of } \\
\text { Subsets }\end{array}$ & Fixed Effect [95\% CI] & $\begin{array}{c}\text { Heterogeneity } \\
\text { Test }(p \text {-Value })\end{array}$ & $\begin{array}{c}\text { Random Effect [95\% CI] } \\
\text { Egger's Test } \\
(p \text {-Value })\end{array}$ \\
\hline Age & & & & & \\
IGBC & 41 & $70.239[69.945,70.534]$ & $<0.001$ & $65.291[63.867,66.715]$ \\
Laparoscopic & 19 & $69.234[68.703,69.765]$ & $<0.001$ & $64.179[61.280,67.077]$ \\
Using registry & 3 & $71.613[71.208,72.017]$ & 0.083 & $71.149[69.890,72.408]$ \\
Individual & 38 & $68.695[68.265,69.124]$ & $<0.001$ & $64.629[62.801,66.458]$ \\
Overall & 17 & $49.797[49.770,49.824]$ & $<0.001$ & $52.023[49.208,54.839]$ \\
Laparoscopic & 4 & $48.289[48.048,48.529]$ & $<0.001$ & $49.014[43.925,54.103]$ \\
Individual & 17 & $49.797[49.770,49.824]$ & $<0.001$ & $52.023[49.208,54.839]$ \\
\hline Female ratio & & & & 0.524 \\
IGBC & 41 & $0.695[0.668,0.721]$ & 0.113 & 0.199 \\
Laparoscopic & 19 & $0.658[0.607,0.705]$ & 0.671 & $0.694[0.660,0.727]$ \\
Using registry & 3 & $0.735[0.691,0.775]$ & 0.001 & $0.658[0.607,0.705]$ \\
Individual & 38 & $0.673[0.638,0.706]$ & 0.744 & $0.761[0.628,0.857]$ \\
Overall & 23 & $0.683[0.681,0.685]$ & $<0.001$ & $0.673[0.638,0.706]$ \\
Laparoscopic & 6 & $0.661[0.652,0.669]$ & $<0.001$ & $0.689[0.659,0.717]$ \\
Individual & 23 & $0.683[0.681,0.685]$ & $<0.001$ & $0.635[0.584,0.683]$ \\
\hline
\end{tabular}

$\mathrm{CI}$, Confidence interval; IGBC, incidental gallbladder cancer.

Table 4. The estimated rates of tumor stages of incidental gallbladder cancer after cholecystectomy.

\begin{tabular}{cccccc}
\hline Subgroup & $\begin{array}{c}\text { Number of } \\
\text { Subsets }\end{array}$ & Fixed Effect [95\% CI] & $\begin{array}{c}\text { Heterogeneity } \\
\text { Test }(\boldsymbol{p} \text {-Value })\end{array}$ & Random Effect [95\% CI] & $\begin{array}{c}\text { Egger's Test } \\
(\boldsymbol{p} \text {-Value })\end{array}$ \\
\hline $\begin{array}{c}\text { Tumor stage } \\
\text { pTis }\end{array}$ & 17 & $0.125[0.094,0.163]$ & 0.002 & $0.130[0.079,0.206]$ & 0.853 \\
PT1 & 34 & $0.300[0.270,0.331]$ & $<0.001$ & $0.341[0.283,0.403]$ & 0.022 \\
pT2 & 37 & $0.395[0.364,0.426]$ & 0.001 & $0.397[0.348,0.448]$ & 0.957 \\
pT3 & 27 & $0.230[0.203,0.260]$ & 0.253 & $0.227[0.195,0.264]$ & 0.311 \\
pT4 & 8 & $0.156[0.126,0.191]$ & $<0.001$ & $0.125[0.073,0.206]$ & 0.255 \\
\hline
\end{tabular}

CI, Confidence interval.

\subsection{Comparison of Prognosis between IGBC and Non-IGBC}

The prognosis of IGBC was evaluated by comparing it to non-IGBC. Patients with IGBC had a better overall survival rate than patients with non-IGBC (HR 0.574, 95\% CI 0.445-0.739; Figure 2). However, there was no significant difference of the disease-free survival rate between patients with IGBC and non-IGBC (HR 0.931, 95\% CI 0.618-1.402). 
A

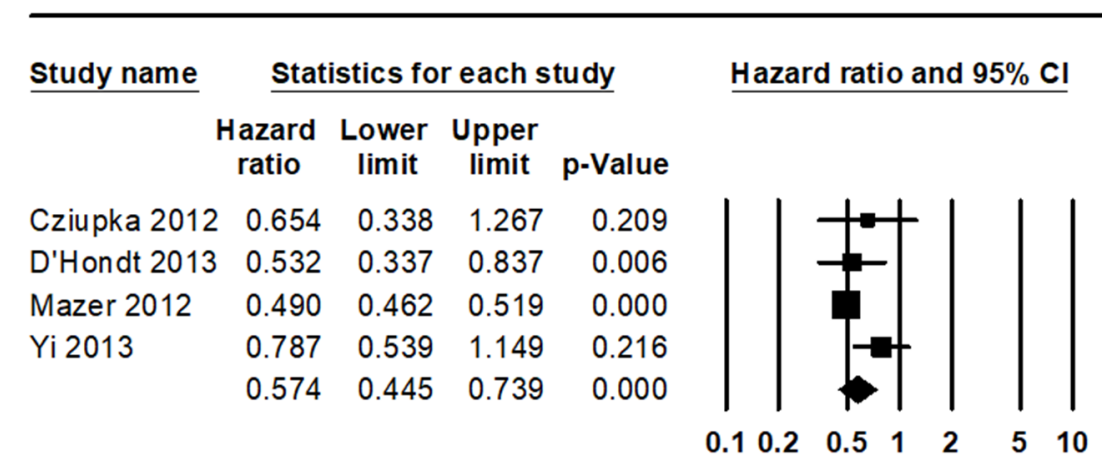

B

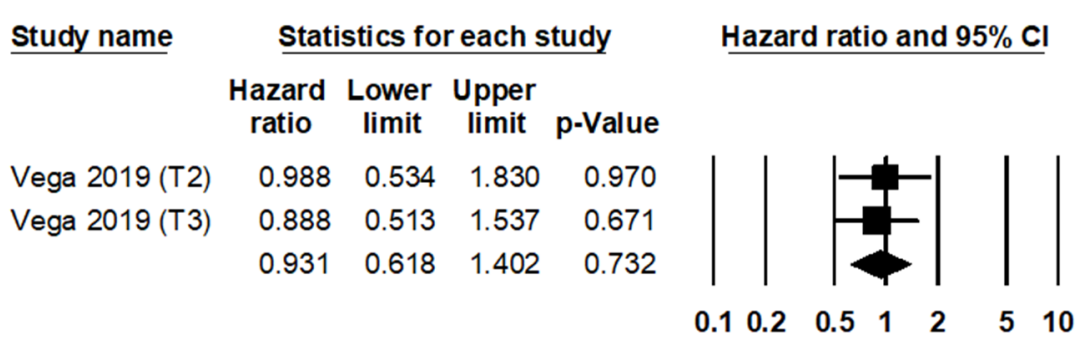

Figure 2. Forest plots for the differences of the survival rates between incidental gallbladder cancer (IGBC) and non-IGBC. (A) Overall survival and (B) disease-free survival.

\section{Discussion}

To the best of our knowledge, the present study is the first meta-analysis to investigate the incidence rate of IGBC and to compare the prognosis of IGBC and non-IGBC patients. Previous studies, including systematic reviews and meta-analyses, have reported IGBC after cholecystectomy. The previous meta-analysis showed the incidence rate and the prevalence of $\mathrm{pT}$ stage of IGBC using 26 eligible studies [59]. However, the information for the prognosis of IGBC cannot be obtained in the previous meta-analysis. We also analyzed the incidence rates according to the type of surgery and study and the patients' age and sex.

Eligible studies of the current meta-analysis showed the information for the combined group with laparoscopic and open cholecystectomy or laparoscopic cholecystectomy alone. Among the eligible studies, data for the incidence of IGBC after open cholecystectomy could not be obtained. In daily practice, laparoscopic cholecystectomy is a gold standard for benign diseases of GB rather than open cholecystectomy. However, the comparison of the incidence rate of IGBC between laparoscopic and open cholecystectomies could not be performed due to no information for open cholecystectomy.

We indirectly compared the incidence rates between patients with laparoscopic cholecystectomy and overall patients. The estimated incidence rates of IGBC were $0.7 \%$ and $0.6 \%$ in patients with laparoscopic cholecystectomy and overall patients, respectively. The incidence rates ranged from $0.1 \%$ to $2.9 \%$ in the eligible studies. Eligible studies obtained the information from a single individual hospital or public registry. The estimated incidence rate of the single individual hospital was significantly higher than that of the public registry $(0.7 \%$ vs. $0.2 \%)$. This discrepancy may be caused by the size of the population and different hospitals. In addition, because single individual hospital data may be obtained from tertiary hospitals or training hospital, the ratio of elective cholecystectomy with benign diseases can be lowered.

Unlike the previous meta-analysis, we performed the meta-analysis for the overall and disease-free survival rates of IGBC compared to non-IGBC. However, the information for the disease-free survival rate was only shown in one study [48]. As this study showed the disease-free survival rates divided into pT2 and pT3 stages, the meta-analysis could be performed. However, there was no significant 
difference of the disease-free survival between patients with IGBC and non-IGBC. In the comparison of overall survival rates, patients with IGBC had a favorable prognosis compared to patients with non-IGBC. However, among eligible studies, some studies demonstrated no significant difference of overall survival rates [12,51].

This difference of prognosis between IGBC and non-IGBC may be caused by the difference of the tumor stage at the initial diagnosis (pT stage) in IGBC than in non-IGBC. In the current meta-analysis, IGBCs were detected from pTis to pT4. The highest rate of pT stage was the pT2 stage in IGBC $(39.7 \%$, $95 \%$ CI 34.8-44.8\%). In the current study, patients with IGBC were frequently confirmed to pTis to pT2 stages. The pT3 and pT4 stages were $22.7 \%$ and $12.5 \%$, respectively. However, the previous meta-analysis reported that the pT4 stage rate of IGBC was $4.2 \%$ (Choi KS 2015). In addition, patients with a lower $\mathrm{pT}$ stage had better survival rates than those with a higher $\mathrm{pT}$ stage, regardless of preoperative suspicion [12,33]. Thus, the lower pT stage of IGBC may impact the better prognosis of IGBC compared to non-IGBC. Further evaluation for the prognosis of IGBC and non-IGBC will be needed based on the stratification of $\mathrm{pT}$ stage. As the extent of pathologic examination can impact the pT stage, further evaluations are needed.

A previous study reported that the preoperative nonsuspicious cases were $50-70 \%$ of the overall GBCs $[54,60]$. For the detection of GBC in the postoperative pathologic examination, the appropriate sections are needed for the suspicious lesion. However, in daily practice, because all portions of GB cannot be evaluated in the microscopic examination, the careful macroscopic examination from expert pathologists may be important. Previous studies suggested the effect of frozen sections on the detection of IGBC $[4,36]$.

The intraoperative detection of IGBC with pT2 or higher stages via frozen sections can be useful for the prompt conversion of radical surgery [47]. The rates of pTis and pT1 stages were $13.0 \%$ and $34.1 \%$, and the frozen section was not useful for non-mass-forming GBC. Therefore, in pT2 and higher stages, the intraoperative frozen may be useful for infiltrative lesions into the adjacent tissue. Nitta et al. [36] suggested that the examination for the full thickness of the gallbladder through the frozen section could be useful for the detection of IGBC and differentiation between pTis/T1a and others. The most common macroscopic feature is the wall thickening of GBC. As there are limitations on the extent and time of examination of frozen sections, the impact on the detection of IGBC is limited. Frozen sections can be useful for suspicious lesions detected by surgeons [4].

Some limitations in the current meta-analysis exist. First, in this meta-analysis, the $\mathrm{pN}$ stage and nodal disease were not analyzed. Laparoscopic cholecystectomy is enough for treatment for IGBC with the pTis to pT1 stage. Therefore, lymph node dissection could not be performed in many cases with IGBC. Second, by definition, missing cases in the preoperative radiologic examination should be considered for non-IGBC. However, the detailed information for preoperative radiologic findings could not be found in the eligible studies. Based on this limitation, the incidence rate of IGBC may be lower. Third, the present study was not performed for the subgroup analysis for tumor types, such as lymphoma and squamous cell carcinoma, due to the very low incidence of other tumor types. Fourth, the detailed comparisons between IGBC and benign diseases could not be performed due to insufficient information on eligible studies. However, IGBC frequently occurred with older age and male subjects, compared to benign diseases. Fifth, the impact of histologic examination on the detection rate of IGBC could not be investigated due to insufficient information of the examined section or extent. Sixth, the impact of pT stages of IGBC on survival rates could not be obtained due to insufficient information. Seventh, subgroup analysis based on the types of benign diseases, such as acute/chronic cholecystitis, could not be obtained due to insufficient information.

\section{Conclusions}

In conclusion, IGBC was found in $0.6 \%$ of cholecystectomy with benign diseases. IGBCs had higher rates in the pT1 and pT2 stages and frequently occurred in older patients. In addition, patients with 
IGBCs had a better prognosis than those with non-IGBCs. To detect IGBC after cholecystectomy, a sufficient examination for histology is needed in the pathologic examination.

Author Contributions: Conceptualization, J.-S.P. and B.K.S.; supervision, B.K.S.; methodology, J.-S.P.; software, J.-S.P. and B.K.S.; writing-original draft preparation, J.-S.P.; writing—review and editing, H.Y.L., I.W.O., K.H.C., and B.K.S. All authors have read and agreed to the published version of the manuscript.

Conflicts of Interest: The authors declare that they have no conflict of interest.

\section{References}

1. WHO Classification of Tumors Editorial Board. WHO Classification of Tumours of the Digestive System, 5th ed.; International Agency for Research on Cancer: Lyon, France, 2019.

2. Levy, A.D.; Murakata, L.A.; Abbott, R.M.; Rohrmann, C.A., Jr. From the archives of the AFIP. Benign tumors and tumorlike lesions of the gallbladder and extrahepatic bile ducts: Radiologic-pathologic correlation. Armed Forces Institute of Pathology. Radiographics 2002, 22, 387-413. [CrossRef] [PubMed]

3. Ahn, Y.; Park, C.-S.; Hwang, S.; Jang, H.-J.; Choi, K.-M.; Lee, S.-G. Incidental gallbladder cancer after routine cholecystectomy: When should we suspect it preoperatively and what are predictors of patient survival? Ann. Surg. Treat. Res. 2016, 90, 131-138. [CrossRef] [PubMed]

4. Aoki, T.; Tsuchida, A.; Kasuya, K.; Inoue, K.; Saito, H.; Koyanagi, Y. Is frozen section effective for diagnosis of unsuspected gallbladder cancer during laparoscopic cholecystectomy? Surg. Endosc. 2001, 16, 197-200. [CrossRef] [PubMed]

5. Apodaca-Rueda, M.; Cazzo, E.; De-Carvalho, R.B.; Chaim, E.A. Prevalência do câncer de vesícula biliar em pacientes submetidos à colecistectomia: Experiência do Hospital de Clínicas da Faculdade de Ciências Médicas da Universidade Estadual de Campinas-UNICAMP. Revista Colégio Bras. Cir. 2017, 44, 252-256. [CrossRef]

6. Basak, F.; Hasbahceci, M.; Canbak, T.; Sisik, A.; Acar, A.; Yucel, M.; Bas, G.; Alimoĝlu, O. Incidental findings during routine pathological evaluation of gallbladder specimens: Review of 1747 elective laparoscopic cholecystectomy cases. Ann. R. Coll. Surg. Engl. 2016, 98, 280-283. [CrossRef]

7. Braghetto, I.; Bastias, J.; Csendes, A.; Chiong, H.; Compan, A.; Valladares, H.; Rojas, J. Gallbladder carcinoma during laparoscopic cholecystectomy: Is it associated with bad prognosis? Int. Surg. 1999, 84, 344-349.

8. Cavallaro, A.S.; Piccolo, G.; Panebianco, V.; Menzo, E.L.; Berretta, M.; Zanghì, A.; Di Vita, M.; Cappellani, A. Incidental gallbladder cancer during laparoscopic cholecystectomy: Managing an unexpected finding. World J. Gastroenterol. 2012, 18, 4019-4027. [CrossRef]

9. Chan, C.-P.; Chang, H.-C.; Chen, Y.-L.; Yang, L.; Chen, S.-T.; Kuo, S.-J.; Tsai, P.-C. A 10-year experience of unsuspected gallbladder cancer after laparoscopic cholecystectomy. Int. Surg. 2003, 88, 175-179.

10. Charfi, S.; Gouiaa, N.; Mnif, H.; Chtourou, L.; Tahri, N.; Abid, B.; Mzali, R.; Boudawara, T.S. Histopathological findings in cholecystectomies specimens: A single institution study of 20584 cases. Hepatobiliary Pancreat. Dis. Int. 2018, 17, 345-348. [CrossRef]

11. Choi, S.B.; Han, H.J.; Kim, C.Y.; Kim, W.B.; Song, T.-J.; Suh, S.O.; Kim, Y.C.; Choi, S.Y. Incidental Gallbladder Cancer Diagnosed Following Laparoscopic Cholecystectomy. World J. Surg. 2009, 33, 2657-2663. [CrossRef]

12. Cziupka, K.; Partecke, L.I.; Mirow, L.; Heidecke, C.-D.; Emde, C.; Hoffmann, W.; Siewert, U.; Berg, N.V.D.; Von Bernstorff, W.; Stier, A. Outcomes and prognostic factors in gallbladder cancer: A single-centre experience. Langenbeck's Arch. Surg. 2012, 397, 899-907. [CrossRef] [PubMed]

13. D’Hondt, M.; Lapointe, R.; Benamira, Z.; Pottel, H.; Plasse, M.; Letourneau, R.; Roy, A.; Dagenais, M.; Vandenbroucke-Menu, F. Carcinoma of the gallbladder: Patterns of presentation, prognostic factors and survival rate. An 11-year single centre experience. Eur. J. Surg. Oncol. (EJSO) 2013, 39, 548-553. [CrossRef] [PubMed]

14. Chabowski, M.; Dorobisz, T.; Dorobisz, K.; Pawlowski, W.; Janczak, D.; Patrzalek, D.; Janczak, D. Incidental gallbladder cancer after cholecystectomy: 1990 to 2014. OncoTargets Ther. 2016, 9, 4913-4916. [CrossRef] [PubMed]

15. Duzkoylu, Y.; Bektas, H.; Kozluklu, Z.D. Incidental gallbladder cancers: Our clinical experience and review of the literature. Turk. J. Surg. 2015, 32, 107-110. [CrossRef] [PubMed] 
16. Ferrarese, A.; Solej, M.; Enrico, S.; Falcone, A.; Catalano, S.; Pozzi, G.; Marola, S.; Martino, V. Diagnosis of incidental gallbladder cancer after laparoscopic cholecystectomy: Our experience. BMC Surg. 2013, 13 , S20. [CrossRef] [PubMed]

17. Firat, Y.D.; Idiz, U.O.; Cakir, C.; Yardimci, E.; Yazici, P.; Bektasoglu, H.; Bozkurt, E.; Ucak, R.; Gucin, Z.; Uresin, T.; et al. Prospective multi-center study of surgeon's assessment of the gallbladder compared to histopathological examination to detect incidental malignancy. Langenbeck's Arch. Surg. 2019, 404, 573-579. [CrossRef]

18. Volkan, G.; Kirimker, E.O.; Akyol, C.; Kocaay, A.F.; Karabörk, A.; Tüzüner, A.; Erden, E.; Karayalçin, K. Incidental gallbladder cancer diagnosed during or after laparoscopic cholecystectomy in members of the Turkish population with gallstone disease. Turk J. Gastroenterol. 2011, 22, 513-516.

19. Geramizadeh, B.; Kashkooe, A. Incidental Gall Bladder Adenocarcinoma in Cholecystectomy Specimens; A Single Center Experience and Review of the Literature. Middle East J. Dig. Dis. 2018, 10, 249-253. [CrossRef]

20. Glauser, P.M.; Strub, D.; Käser, S.A.; Mattiello, D.; Rieben, F.; Maurer, C.A. Incidence, management, and outcome of incidental gallbladder carcinoma: Analysis of the database of the Swiss association of laparoscopic and thoracoscopic surgery. Surg. Endosc. 2010, 24, 2281-2286. [CrossRef]

21. Goussous, N.; Maqsood, H.; Patel, K.; Ferdosi, H.; Muhammad, N.; Sill, A.M.; Kowdley, G.C.; Cunningham, S.C. Clues to predict incidental gallbladder cancer. Hepatobiliary Pancreat. Dis. Int. 2018, 17, 149-154. [CrossRef]

22. Gulwani, H.V.; Gupta, S.; Kaur, S. Incidental Detection of Carcinoma Gall Bladder in Laparoscopic Cholecystectomy Specimens: A Thirteen Year Study of 23 Cases and Literature Review. Indian J. Surg. Oncol. 2015, 6, 30-35. [CrossRef] [PubMed]

23. Horkoff, M.J.; Ahmed, Z.; Xu, Y.; Sutherland, F.R.; Dixon, E.; Ball, C.G.; Bathe, O.F. Adverse Outcomes After Bile Spillage in Incidental Gallbladder Cancers. Ann. Surg. 2019. [CrossRef] [PubMed]

24. Ioannidis, O.; Paraskevas, G.; Varnalidis, I.; Ntoumpara, M.; Tsigkriki, L.; Gatzos, S.; Malakozis, S.G.; Papapostolou, D.; Papadopoulou, A.; Makrantonakis, A.; et al. Primary gallbladder cancer discovered postoperatively after elective and emergency cholecystectomy. Klin. Onkol. 2013, 26, 31-34. [CrossRef] [PubMed]

25. Jha, V.; Sharma, P.; Mandal, K.A. Incidental gallbladder carcinoma: Utility of histopathological evaluation of routine cholecystectomy specimens. South Asian J. Cancer 2018, 7, 21-23. [CrossRef]

26. Kalita, D.; Pant, L.; Singh, S.; Jain, G.; Kudesia, M.; Gupta, K.; Kaur, C. Impact of routine histopathological examination of gall bladder specimens on early detection of malignancy-a study of 4115 cholecystectomy specimens. Asian Pac. J. Cancer Prev. 2013, 14, 3315-3318. [CrossRef]

27. Kim, J.H.; Kim, W.H.; Kim, J.H.; Yoo, B.M.; Kim, M.W. Unsuspected gallbladder cancer diagnosed after laparoscopic cholecystectomy: Focus on acute cholecystitis. World J. Surg. 2010, 34, 114-120. [CrossRef]

28. Koppatz, H.; Nordin, A.; Scheinin, T.; Sallinen, V. The risk of incidental gallbladder cancer is negligible in macroscopically normal cholecystectomy specimens. HPB 2018, 20, 456-461. [CrossRef]

29. Kwon, S.Y.; Chang, H.J. A clinicopathological study of unsuspected carcinoma of the gallbladder. J. Korean Med. Sci. 1997, 12, 519-522. [CrossRef]

30. Kwon, A.H.; Imamura, A.; Kitade, H.; Kamiyama, Y. Unsuspected gallbladder cancer diagnosed during or after laparoscopic cholecystectomy. J. Surg. Oncol. 2008, 97, 241-245. [CrossRef]

31. Lundgren, L.; Muszynska, C.; Ros, A.; Persson, G.; Gimm, O.; Valter, L.; Andersson, B.; Sandström, P. Are Incidental Gallbladder Cancers Missed with a Selective Approach of Gallbladder Histology at Cholecystectomy? World J. Surg. 2018, 42, 1092-1099. [CrossRef]

32. Martins-Filho, E.D.; Batista, T.; Kreimer, F.; Iwanaga, T.C.; Leão, C.D.S.; Martins, A.C.D.A. Prevalence of incidental gallbladder cancer in a tertiary-care hospital from Pernambuco, Brazil. Arq. Gastroenterol. 2015, 52, 247-249. [CrossRef] [PubMed]

33. Mazer, L.M.; Losada, H.F.; Chaudhry, R.M.; Velazquez-Ramirez, G.A.; Donohue, J.H.; Kooby, D.A.; Nagorney, D.M.; Adsay, N.V.; Sarmiento, J.M. Tumor characteristics and survival analysis of incidental versus suspected gallbladder carcinoma. J. Gastrointest. Surg. 2012, 16, 1311-1317. [CrossRef] [PubMed]

34. Mitrovic, F.; Krdzalic, G.; Musanovic, N.; Osmic, H. Incidental gallbladder carcinoma in regional clinical centre. Acta Chir. Iugosl. 2010, 57, 95-97. [CrossRef] [PubMed]

35. Mori, T.; Souda, S.; Hashimoto, J.; Yoshikawa, Y.; Ohshima, M. Unsuspected gallbladder cancer diagnosed by laparoscopic cholecystectomy: A clinicopathological study. Surg. Today 1997, 27, 710-713. [CrossRef] 
36. Nitta, T.; Kataoka, J.; Ohta, M.; Fujii, K.; Takashima, Y.; Inoue, Y.; Ishibashi, T. Surgical strategy for suspected early gallbladder carcinoma including incidental gallbladder carcinoma diagnosed during or after cholecystectomy. Ann. Med. Surg. 2018, 33, 56-59. [CrossRef]

37. Panebianco, A.; Volpi, A.; Lozito, C.; Prestera, A.; Ialongo, P.; Palasciano, N.A.M. Incidental gallbladder carcinoma: Our experience. G. Chir. J. Surg. 2013, 34, 167-169. [CrossRef]

38. Patel, K.; Dajani, K.; Iype, S.; Chatzizacharias, N.A.; Vickramarajah, S.; Singh, P.; Davies, S.; Brais, R.; Liau, S.S.; Harper, S.; et al. Incidental non-benign gallbladder histopathology after cholecystectomy in an United Kingdom population: Need for routine histological analysis? World J. Gastrointest. Surg. 2016, 8, 685-692. [CrossRef]

39. Pitt, S.C.; Jin, L.X.; Hall, B.L.; Strasberg, S.M.; Pitt, H.A. Incidental Gallbladder Cancer at Cholecystectomy. Ann. Surg. 2014, 260, 128-133. [CrossRef]

40. Sarli, L.; Contini, S.; Sansebastiano, G.; Gobbi, S.; Costi, R.; Roncoroni, L. Does laparoscopic cholecystectomy worsen the prognosis of unsuspected gallbladder cancer? Arch. Surg. 2000, 135, 1340-1344. [CrossRef]

41. Shimizu, T.; Arima, Y.; Yokomuro, S.; Yoshida, H.; Mamada, Y.; Nomura, T.; Taniai, N.; Aimoto, T.; Nakamura, Y.; Mizuguchi, Y.; et al. Incidental gallbladder cancer diagnosed during and after laparoscopic cholecystectomy. J. Nippon. Med. Sch. 2006, 73, 136-140. [CrossRef]

42. Solaini, L.; Sharma, A.; Watt, J.; Iosifidou, S.; Aleong, J.-A.C.; Kocher, H. Predictive factors for incidental gallbladder dysplasia and carcinoma. J. Surg. Res. 2014, 189, 17-21. [CrossRef]

43. Talreja, V.; Ali, A.; Khawaja, R.; Rani, K.; Samnani, S.S.; Farid, F.N. Surgically Resected Gall Bladder: Is Histopathology Needed for All? Surg. Res. Pract. 2016, 2016, 9319147. [CrossRef] [PubMed]

44. Tantia, O.; Jain, M.; Khanna, S.; Sen, B. Incidental carcinoma gall bladder during laparoscopic cholecystectomy for symptomatic gall stone disease. Surg. Endosc. 2008, 23, 2041-2046. [CrossRef] [PubMed]

45. Tatli, F.; Ozgönül, O.; Yucel, Y.; Yalcin, H.C.; Ciftci, R.; Gümer, M.; Erkmen, F.; Altuntas, R.; Uzunkoy, C. Incidental gallbladder cancer at cholecystectomy. Ann. Ital. Chir. 2017, 6, 399-402.

46. Tian, Y.-H.; Ji, X.; Liu, B.; Yang, G.-Y.; Meng, X.-F.; Xia, H.-T.; Wang, J.; Huang, Z.; Dong, J.-H. Surgical Treatment of Incidental Gallbladder Cancer Discovered During or Following Laparoscopic Cholecystectomy. World J. Surg. 2014, 39, 746-752. [CrossRef] [PubMed]

47. Utsumi, M.; Aoki, H.; Kunitomo, T.; Mushiake, Y.; Yasuhara, I.; Arata, T.; Katsuda, K.; Tanakaya, K.; Takeuchi, H. Evaluation of surgical treatment for incidental gallbladder carcinoma diagnosed during or after laparoscopic cholecystectomy: Single center results. BMC Res. Notes 2017, 10, 56. [CrossRef]

48. Vega, E.A.; Vinuela, E.; Sanhueza, M.; Mege, R.; Caracci, M.; Diaz, C.; Diaz, A.; Okuno, M.; Joechle, K.; Goumard, C.; et al. Positive cystic duct margin at index cholecystectomy in incidental gallbladder cancer is an important negative prognosticator. Eur. J. Surg. Oncol. (EJSO) 2019, 45, 1061-1068. [CrossRef]

49. Xu, X.; Liu, W.; Li, B.; Hong, T.; Zheng, C.-J.; Wang, C.; Zhao, Y. Unsuspected Gallbladder Cancer During or After Laparoscopic Cholecystectomy. Chin. Med. Sci. J. 2013, 28, 102-106. [CrossRef]

50. Yamamoto, H.; Hayakawa, N.; Kitagawa, Y.; Katohno, Y.; Sasaya, T.; Takara, D.; Nagino, M.; Nimura, Y. Unsuspected gallbladder carcinoma after laparoscopic cholecystectomy. J. Hepato Biliary Pancreat. Surg. 2005, 12, 391-398. [CrossRef]

51. Yi, X.; Long, X.; Zai, H.; Xiao, D.; Li, W.; Li, Y. Unsuspected gallbladder carcinoma discovered during or after cholecystectomy: Focus on appropriate radical re-resection according to the T-stage. Clin. Transl. Oncol. 2013, 15, 652-658. [CrossRef]

52. Zhang, W.; Xu, G.-F.; Tian, Z.-Q.; Wu, G.-Z.; Wang, H.; Guan, W.-X. Surgical approach does not influence the outcome of incidental gallbladder carcinoma. Int. J. Clin. Exp. Med. 2015, 8, 869-875. [PubMed]

53. Zhu, J.-Q.; Han, D.-D.; Li, X.-L.; Kou, J.-T.; Fan, H.; He, Q. Predictors of incidental gallbladder cancer in elderly patients. Hepatobiliary Pancreat. Dis. Int. 2015, 14, 96-100. [CrossRef]

54. Shih, S.P.; Schulick, R.D.; Cameron, J.L.; Lillemoe, K.D.; Pitt, H.A.; Choti, M.A.; Campbell, K.A.; Yeo, C.J.; Talamini, M.A. Gallbladder Cancer: The Role of Laparoscopy and Radical Resection. Ann. Surg. 2007, 245, 893-901. [CrossRef] [PubMed]

55. Jemal, A.; Siegel, R.; Ward, E.; Murray, T.; Xu, J.; Smigal, C.; Thun, M.J. Cancer statistics, 2006. CA. Cancer J. Clin. 2006, 56, 106-130. [CrossRef] [PubMed]

56. Alves, K.R.; Goulart, A.C.; Ladeira, R.M.; de Oliveira, I.R.S.; Benseñor, I.M. Frequency of Cholecystectomy and Associated Sociodemographic and Clinical Risk Factors in the ELSA-Brasil Study. Sao Paulo Med. J. 2016, 134, 240-250. [CrossRef] [PubMed] 
57. Stinton, L.M.; Shaffer, E.A. Epidemiology of Gallbladder Disease: Cholelithiasis and Cancer. Gut Liver. 2012, 6, 172-187. [CrossRef]

58. Yusuf, S.; Peto, R.; Lewis, J.; Collins, R.; Sleight, P. Beta blockade during and after myocardial infarction: An overview of the randomized trials. Prog. Cardiovasc. Dis. 1985, 27, 335-371. [CrossRef]

59. Choi, K.S.; Choi, S.B.; Park, P.; Kim, W.B.; Choi, S.Y. Clinical characteristics of incidental or unsuspected gallbladder cancers diagnosed during or after cholecystectomy: A systematic review and meta-analysis. World J. Gastroenterol. 2015, 21, 1315-1323. [CrossRef]

60. Goetze, T.; Paolucci, V. Does laparoscopy worsen the prognosis for incidental gallbladder cancer? Surg. Endosc. 2005, 20, 286-293. [CrossRef]

(C) 2020 by the authors. Licensee MDPI, Basel, Switzerland. This article is an open access article distributed under the terms and conditions of the Creative Commons Attribution (CC BY) license (http://creativecommons.org/licenses/by/4.0/). 